\title{
THE EVALUATION OF FREIGHT FORWARDING BUSINESS EXISTENCES
}

\author{
Arum Anggorowati ${ }^{1}$ \\ 1. STMT Trisakti \\ Corresponding Author :arum.anggorowati@gmail.com
}

\begin{abstract}
Freight forwarding business is one of developing businesses in Indonesia. The existence of the business is supported by the existence of export and import activities carried out by the other business doers. Companies involved in freight forwarding are manufactures, trading, retailer, consumer goods, and many others. Most of the companies do exporting and importing in the sustainability of the suffering business condition. There are two types of cargos; general cargo, and special cargo that requires special handling. The existence of a freight forwarding company might possibly be outlasted. The decreasing of global economic condition causes a tight business competition between freight forwarders. Some other factors can also be threats to the existence of the freight forwarding business in Indonesia.
\end{abstract}

Keywords : Freight forwarder, freight forwarder business, export and import

\section{Introduction}

Freight Forwarder is a company involved in the service of shipping goods or cargo.Various transportation modes are used in shipping, such as,land, sea, and air transportation. The activities carried out by freight forwarder are shipping, receiving goods, storage of goods, packing, weighing, labeling, and publishing the transport document.Currently, industrial companies mostly support the growth of companies in Indonesia. The more industrial companies that set up factory plantin Indonesia, the faster economic development and prosperity this country will achieve. The existence of the industrial companies is certainly connected with the activity of transport and logistics. Related developments and progress in the field of industry, then the Government gives some conveniences to the entrepreneur to be able to do a variety of activities that can support the effort they went through, one is the activities of export or import.

Business activities always deal with transportation and logistics, export and import handling, factory warehousing and various other supporting activities. 
As for some of the services offered by the company such as a freight forwarder, customs clearance services handling good export as well as import, handling as a distribution center, provides warehousing, provides unloading and unpacking temporary positioning for cargo. Some services provided by the company facilitate the freight forwarder and support the business of the company and in the field of manufacturing, trading, retail company as well. .

\section{Method}

- Export

According to Husni Hasan et.al (2012:64), export is the process of transportinggoods or commodities from one country to another legally, generally conducted in the trading process. The export process in general is the action to remove the goods or commodities from the country to integrate it into other countries.

An export process can be said to be an enterprise's success in generating a yield of production, which produced such acclaimed quality and can compete with other products in the world.It is a competitive advantage for the company.

- Import

"Imports are ingoing the goods from abroad into the customs territory of Indonesia in some required conditions" (Djauhari, 2007:1)

"Imports are goods and services incorporating activities into the area of customs in accordance with the regulations and the applicable militate an invitation." (Astuti and Sri, 2013:1)

Of the few definitions concerning import expressed by the experts above, it can be stated that the import is economic activity by inflowing goods from outside the area into the territory.

- Freight Forwarding Business

According to Human Resources Logistic (2008) in (Baharudin, 2012), the management of transport services (freight forwarding) is intended to 
represent the interests of the owner of the goods to take care of all the activities necessary for the implementation of the delivery or acceptance of the goods, either by land, sea or air transportation. The activities include the receiving, storing, sorting, packing, marking, measuring, weighing, and maintaining the settlement document. Furthermore, publishing transport document, calculating of costs, transporting insurance, claiming over the delivery of the goods as well as the settlement of bills and other costs concerning delivery of these items as of the receipt of the goods are the other activities.

In addition, there are also a definition defined by BusinessDictionary.com, which is firm specializing in arranging storage and shipping of merchandise on behalf of its shippers. Freight forwarder usually provides a full range of services including: tracking inland transportation, preparation of shipping and export documents, warehousing, cargo space booking, negotiating freight charges, freight consolidation, cargo insurance, and filing of insurance claims.

Freight forwarders usually ship under their own bills of lading or air waybills (called house bill of lading or air waybill house) and their agents or associates at the destination (overseas freight forwarders) provide delivery document, deconsolidation, and freight collection servicesalso called forwarder.

That definition is a little wordy and sounds complicated, so let's just do a basic definition as follows: A freight forwarder is a company that arranges you importing and exporting of goods or cargos.

1. What does a freight forwarder actually do

According to WyndRizaldyet.al (2013:8), the duties and responsibilities of a freight forwarder in his position as an intermediary between exporter and importer areas follows.

a. Provide an important source of information for the users of the service to determine on a buy/sell agreement with certain parties.

b. As a Media to help service users identify who and how is the ability of the prospective partners. 
c. The owner of the goods has the right to obtain maximum service from the carrier (the freight forwarder)aligned with the charge that has been assigned to him (the carrier) to send the goods to the destination.

d. Help producers as well as other business community to acquire new market locations in several countries in the world, so that their products would gain a new market area.

In addition, there are many things to be concerned of and prepared to control international shipping, either export or import. First,we need to recognize the activities of the freight forwarder in the process of export or import. The main point is, a freight forwarding company does not organize the delivery of cargo by simply using their own services, but using the services of other companies related to export and import activities.

Therefore, the freight forwarding company is an intermediary between the customer (shipper/consignee) with other transportation services companies, such as shipping line, airline, trucking company, and the railways company.

In freight forwarding business, a freight forwarder must create a good relationship with the airline, shipping line, trucking, and the railway companies. By having a good relationship and cooperation, the company may obtain the best price in freight. As a result, the costs arising from export and import activities can reach the point of economic efficiency.

Freight forwarder has obligation to give an advice to shipper or the consignee related to export and import running process., In order to make the export and import processes run more efficiently from one destination to another destination. In addition, a freight forwarder will provide guidance in the preparation of shipping documents required to process customs, regulations in force, the transportation preference, fees acquired and etcetera. 
2. Why Should we use a freight forwarder

A freight forwarding company runs the activities of export import and gives many advantages for shipper or the consignee. Good service from a freight forwarder can save time for shipper /consignee in setting up various things related to such export and import process. In this case, shipper or consignee does not have to think about the selection of transportation and the competitive rate.

In order to minimize transportation and logistics cost of a business, and improve the effectiveness and efficiency of exportimport, many companies (exporters) consider that using freight forwarding service is the best way at all. That many companies have such an opinion is an opportunity, making many freight forwarders emerges (Ricardianto, n.d., 2015)

The existence of freight forwarder gave an important role in the smooth export and import process, especially if a company does not have a special permit or license for export and import activities. In this case, freight forwarder plays extremely positive role.

There are many advantages in using a freight forwarder, among others are :

- A Freight Forwarder handles supplementary services that are the part of the international shipping business, such as : Insurance, Customs Documentation, and etc

- A Freight Forwarder provides facilities to consolidate shippers:

1. Non-Vessel Operating Common Carrier documentation

2. Bills of Lading

3. Warehousing

4. Risk Assessment and Management

5. Methods of International Payment, and etc. 


\section{Discussion and Results}

The existence of the company's freight forwarder was certainly influenced by the business activities of other firms, such as manufacturing companies, trading companies, retailers, and others. The business activities of that companies which will affect the volume of exports and imports of a country. The following data export and import volume of the year 2012 - 2016, based on the data of the Central Bureau of statistics (BPS):

Table 1 Export and import Volume of 2012 - 2016 (a unit of tons)

\begin{tabular}{|l|l|l|l|}
\hline No. & Year & Export & Import \\
\hline 1 & 2012 & $600,137,347$ & $136,373,421$ \\
\hline 2 & 2013 & $700,005,037$ & $141,109,588$ \\
\hline 3 & 2014 & $549,465,743$ & $147,734,282$ \\
\hline 4 & 2015 & $509,661,765$ & $147,093,349$ \\
\hline 5 & 2016 & $514,784,576$ & $152,025,371$ \\
\hline
\end{tabular}

Source: BadanPusatStatistik

From thedata above, it can be known that the volume of export and import in Indonesia has the potential to be good enough, although it had experienced a decline in the volume of exports from the year 2013 2016 , but on the other hand, imports showed a current increase in volume that is good enough every year. Referring to the data, the degree of probability of a freight forwarding company can be said to be potentially good enough for maintaining activity of the business.

In addition to the export and import volume table, the following table shows data of loading and unloading goods, transport flow overseas in four (4) major ports in Indonesia:

\section{Table 2}

Volume of loading and unloading export import cargos in 4 (four) main port.

\begin{tabular}{llllllll}
\hline No & Description & Unit & $\mathbf{2 0 1 2}$ & $\mathbf{2 0 1 3}$ & $\mathbf{2 0 1 4}$ & $\mathbf{2 0 1 5}$ & $\mathbf{2 0 1 6}$ \\
\hline $\mathbf{1}$ & BELAWAN & & & & & & \\
& Export & TON & $2,046,223$ & $8,625,452$ & $9,322,665$ & $3,398,976$ & $3,274,754$ \\
& & & $3,458,999$ & $3,123,243$ & $2,993,451$ & $2,403,263$ & $2,408,767$ \\
& Import & & & & & &
\end{tabular}


Table 2, cont.

Volume of loading and unloading export import cargos in 4 (four) main port.

2 TG. PRIOK

\begin{tabular}{|c|c|c|c|c|c|c|c|}
\hline & $\begin{array}{l}\text { Export } \\
\text { Import }\end{array}$ & $\begin{array}{l}\text { TO } \\
\mathbf{N}\end{array}$ & $\begin{array}{l}5,058,334 \\
18,840,11 \\
9\end{array}$ & $\begin{array}{l}3,934,116 \\
18,395,51 \\
5\end{array}$ & $\begin{array}{l}3,735,862 \\
16,656,01 \\
6\end{array}$ & $\begin{array}{l}3,100,423 \\
16,358,80 \\
1\end{array}$ & $\begin{array}{c}189,850 \\
7,610,994\end{array}$ \\
\hline 3 & $\begin{array}{l}\text { TG. } \\
\text { PERAK } \\
\text { Export } \\
\text { Import }\end{array}$ & $\begin{array}{l}\text { TO } \\
\mathrm{N}\end{array}$ & $\begin{array}{l}657,457 \\
7,067,544\end{array}$ & $\begin{array}{l}479,780 \\
7,741,849\end{array}$ & $\begin{array}{l}715,643 \\
7,539,112\end{array}$ & $\begin{array}{l}413,360 \\
8,049,756\end{array}$ & $\begin{array}{l}470,418 \\
8,127,745\end{array}$ \\
\hline 4 & $\begin{array}{l}\text { MAKASSA } \\
\mathbf{R} \\
\text { Export } \\
\text { Import }\end{array}$ & $\begin{array}{l}\mathrm{TO} \\
\mathrm{N}\end{array}$ & $\begin{array}{l}227,717 \\
1,347,330\end{array}$ & $\begin{array}{l}192,163 \\
1,143,477\end{array}$ & $\begin{array}{l}225,362 \\
1,155,311\end{array}$ & $\begin{array}{l}591,150 \\
1,445,864\end{array}$ & $\begin{array}{l}412,879 \\
1,385,467\end{array}$ \\
\hline & $\begin{array}{l}\text { TOTAL } \\
\text { EXPORT }\end{array}$ & & $7,989,731$ & $\begin{array}{l}13,231,51 \\
1\end{array}$ & $\begin{array}{l}13,999,53 \\
2\end{array}$ & $7,503,909$ & $4,347,901$ \\
\hline & IMPORT & & $\begin{array}{l}30,713,99 \\
2\end{array}$ & $\begin{array}{l}30,404,08 \\
4\end{array}$ & $\begin{array}{l}28,343,89 \\
0\end{array}$ & $\begin{array}{l}28,257,68 \\
4\end{array}$ & $\begin{array}{l}19,532,97 \\
3\end{array}$ \\
\hline
\end{tabular}

Source: Transport Statistics Book Vol I, year 2016

From the data above, the average growth of loading or unloading goods per year 2012 - 2016 flow transportation abroad in 4 (four) main port for export has decreased $4.26 \%$, imports declined $9.74 \%$, with each port for exports increased Belawan 65.60\%, decreased 34.54\% Tanjung Priok, Tanjung Perak declined 1.58\%, Makassar increased 33.45\%. whereas on import activities, successive - join in Belawan declined $8.34 \%$, decreased $16.77 \%$ of Tanjung Priok, Tanjung Perak increased 3.67\%, and Makassar experience increased 1.72\%. (source: Transport Statistics Book Vol I, year 2016).

Refer to the last data in the year 2016, known that from 4 (four) main port that can handle the loading and unloading process to reach the 
figure of $23,880,874$ tons of cargo. With the figure referable business that freight forwarding currently has great potential to grow and survive. Nevertheless, the freight forwarding company should still consider it other things that support the existence of the business for the future.

Here are a few things that have probabilities of a threat to the existence of freight forwarding business:

- The level of an economy that is experiencing the sluggishness, this phenomenon occurs not only in Indonesia, but globally.

- The rising prices of basic goods, basic commodities, such as fuel $(\mathrm{BBM})$, electricity, and others. It has became a factor in the decline of the export figures, with the increase of basic commodities price will be a domino effect conferring against rising prices of goods to be exported. Increasing prices of export goods can be impact to lower level of competitiveness of the goods on the international market.

- The reality of the State of the transport infrastructure facilities and infrastructure that have yet to reach all areas in Indonesia, can cause the cost of transportation and logistics rocket, thus causing any freight forwarding companies offering higher price to their customers.

- Freight forwarding business competitor, another threat for this business existence. The growth of freight forwarder business in Indonesia, it means more cargo come into (import) and out of Indonesian territory (export). At this stage, freight forwarding business still have a very tight competition to catch more customers at their business. Based on this situation, it is important for freight forwarding companies in order to maintaining or even do an improvement of their service (Setiawan, 2015)

The above explanations are the facts that freight forwarding businesses are developing. However, they have few threats following their existences. Therefore, a freight forwarder is currently required not only 
to be intermediaries (brokers) for export or import. More than that, a freight forwarder must innovate against their services. Have a good strategy and persisting competition will be one of the keys to maintain the existence of the business.

As effort to maintain the related existence performance of freight forwarding business, then each freight forwarding company is required to perform some points as follow :

- Analyzing market

Freight forwarding company prosecuted for being able to know more information, which related to the latest updates in export and import activities. It can be associated with cargo trend in exports and imports, the incoterm which often selected by customer for their export and import process. As for internal and external factors can affect the business activities' performance, therefore a freight forwarding company is expected to read the situation (environment) that happen around.

Environment, it seems like a source of data and information and the higher of environmental certainty. Environmental certainty could be meant as a level of unpredictability of the environment. Once freight forwarding proceed an analyzing market, they should also consider the external environment, because it can't be regulated by themselves (Bae, 2011)

- One stop solution for logistics service

By providing ease of service to the customer, it can be a business attraction for customers to use the services of freight forwarding. A freight forwarding company is expected to provide logistic services as an integrated solution. Logistics integrated service is intended as a service that covers the overall activities of transportation and logistics service, door to door, door to port, port to door, or port to port. With the availability of the services of ocean freight services, land transportation service (trucking), customs clearance service, 
warehouse management, up to the unloading process of unpacking and positioning in customer plant.

In logistics and supply chain, suppliers, manufacturers, and retailers business, usually rely upon the third party logistics providers to offer logistics services designed to meet their requirements. To do so, third party logistics providers have to interact and directly contact with other supply chain participants on joint problem solving, planning processes, and continuous improvement efforts. In this case, we define integrated logistics relationship as trust and collaboration between Third party logistics providers and other participants that related with supply chain. By engaging in integrated logistics relationships, the suppliers, manufacturers, retailers, and third party logistics providers communicate on a regular basis to make rational inventory or warehouse management and distribution plans. The integrated logistics relationship can supplies resources and assets that any single party in the supply chain may not have. This relationship can also meet with customer expectations and save on logistics costs. (Zhang \& Okoroafo, 2015)

- Doing improvement with Kaizen method

Kaizen is one of continuous improvement process implemented in organizations, and businesses worldwide also adopted Kaizen as a way of doing business (Agmoni, 2016).

Hold kaizen program is an effort to encourage an increase in the company's service improvement of freight forwarding. With the existence of the Plan - Do - Check - Action, it is expected that freight forwarding companies can control their activities better.

- Build customer relationship

To establish a network with the new customer is indeed important, but maintaining good relations with an existing customer is as important as building a network with new customer, as we have thus have probability can recommend us to their business partners. 
Engage with customer also can be through by given rewarding service, through this way customer will likely be more loyal to our business. In addition, the company expected freight forwarding may be able to provide personal services to all customer, by delivering a good quality of service, image branding, and customer satisfaction, this business expect a good customer loyalty and a strong customer relationship (Nurlita et al., 2016).

The customer who have built strong relationship with a company will order the product or service more frequently. Customers who are loyal will be responsive to buy each product or service that provided by the company, and will be increasing the demand (J. \& R. B., 2017)

- The intervention of Government support As similar to other business, freight forwarding also needs some intervention as the Government support. In this case the Government support can be in many forms, such as support in logistics and transportation infrastructure improvement, as outlined earlier, one of alternatives is reducing transportation and logistics costs which makes equitable development of infrastructure in Indonesia. The support of government also can be through a regulation, program, and strategy that have a value added for transportation and logistics activities (S, n.d.) (Sarinah, 2016)

\section{Conclusion}

Based on the above discussion, it is known that freight forwarding business has contributions in supporting the activities of a country's economy, especially in sectors of export and import. The expansion of the manufacturing companies, trading, retail, and others, becomes a very potential business opportunities for freight forwarding company.

A growing number of companies are manufacturing, trading, and retail. They are important points for the existences of the freight forwarding business. Along with the development of those companies, they bring 
positive effect on the growth of many freight forwarding companies in Indonesia.

They can also be said as threats to the existence of a freight forwarder, but they can also be anticipated by means of improving the service quality, and serviceinnovations. The positive output of freight forwarding services are competitive.

The condition of the transportation infrastructure in Indonesia has not been evenly distributed as it is expected to be soon addressed by Government. The existence of support from the Government by developing transportation infrastructure conditions, that reach all areas in Indonesia, is expected to minimize the cost of transportation and logistics. Getting lower cost of transportation and logistics will be a stimulant for the business doers of the industry to do the export and import trade activities.

\section{References}

Agmoni, E. (2016). The Role of Kaizen in Creating Radical Performance Result in a Logistics Service Provider. Logforum, 12(3), 225-245. https://doi.org/10.17270/J.LOG.2016.3.4

Bae, H. S. (2011). The relationships between environment, integration and performance in supply chain contexts. Asian Journal of Shipping and Logistics, 27(1), 61-90. https://doi.org/10.1016/S2092-5212(11)800039

Djauhari, Ahsjar; Export \& Import Transaction Guidelines, achievements, Heirloom, 2007.

Hasan, Husni; et.al.; The popular Dictionary of transport and Logistics, ST Mediakom Trisakti, Jakarta, 2011.

J., S., \& R. B., I. (2017). Building Customer Retention in on-Line Transportation. Budowanie Relacji Z Klientem W Transporcie onLine., 15(2), 229-239. https://doi.org/10.17512/pjms.2017.15.2.21

Nurlita, L., Sekolah, S., Manajemen, T., Trisakti, T., Made, I., Sekolah, A., ... Trisakti, M. T. (2016). Loyalitas Pelanggan Pada Perusahaan Freight Forwarding Customer Loyalty of Freight Forwarding Company, 3(3), 299-308.

Ricardianto, P. (n.d.). Handling Standard Operating Procedure Export Document Ocean Freight, 2(1).

Rizaldy, Wynd; et.al.; Multimoda Transportation Management and Freight Forwarder, STMT Trisakti, Jakarta, 2013.

S, T. I. H. (n.d.). MULTIMODA DALAM MEWUJUDKAN VISI LOGISTIK INDONESIA 2025, 69-84. 
Setiawan, A. (2015). BUSINESS STRATEGY OF PT MONANG SIANIPAR ABADI ( MSA ) CARGO SOEKARNO HATTA CENGKARENG IN 2015, 35-45.

Zhang, H., \& Okoroafo, S. C. (2015). Third-Party Logistics (3PL) and Supply Chain Performance in the Chinese Market: A Conceptual Framework. Engineering Management Research, 4(1), 38-48. https://doi.org/10.5539/emr.v4n1p38

Transport Statistics book, 2016, and https://www.bps.go.id/ www.businessdictionary.com/ 